\title{
EFEK ANTIINFLAMASI NANOPARTIKEL KITOSAN-EKSTRAK KERING TERIPANG (Stichopus variegatus) SECARA IN VITRO DAN IN VIVO
}

\author{
IN VITRO AND IN VIVO ANTI-INFLAMMATORY EFFECTS OF \\ CHITOSAN NANOPARTICLES-DRIED EXTRACT OF SEA \\ CUCUMBER (Stichopus variegatus)
}

\author{
Ema Hermawati $^{1 *}$, Syamsudin Abdillah $^{2}$, Deni Rahmat ${ }^{2}$ \\ ${ }^{1}$ Magister Ilmu Kefarmasian Fakultas Farmasi, Universitas Pancasila, \\ ${ }^{2}$ Fakultas Farmasi, Universitas Pancasila, Jakarta, Indonesia \\ *Penulis Koresponding, e-mail: emahermawati2011@gmail.com
}

\begin{abstract}
ABSTRAK
Ekstrak teripang mengandung glukosamin yang berpotensi dapat menekan peradangan (inflamasi) dan menyembuhkan osteoarthritis. Penelitian ini bertujuan untuk menguji aktivitas antiinflamasi secara in vitro dan in vivo dari nanopartikel kitosan-ekstrak kering teripang (Stichopus variegatus). Aktivitas antiinflamasi secara in vitro dilakukan dengan metode denaturasi protein Bovine Serum Albumin (BSA). Aktivitas antiinflamasi secara in vivo dilakukan dengan metode induksi karagenan pada telapak kaki tikus dengan parameter pengukuran edema kaki. Penelitian ini menggunakan tikus putih jantan galur Sprague-Dawley dan dibagi menjadi 4 kelompok yaitu kelompok yang diberi nanopartikel kitosan-ekstrak teripang kering dosis $50 \mathrm{mg} / \mathrm{KgBB}$ dan $100 \mathrm{mg} / \mathrm{Kg} \mathrm{BB}$, kelompok kontrol negatif (aquadest) serta kelompok kontrol positif (natrium diklofenak). Hasilnya menunjukkan bahwa sampel nanopartikel memiliki aktivitas antiinflamasi secara in vitro dengan nilai IC50 sebesar 267,76 bpj. Nanopartikel kitosan-ekstrak teripang kering dosis $50 \mathrm{mg} / \mathrm{Kg} \mathrm{BB}$ dan $100 \mathrm{mg} / \mathrm{KgBB}$ memiliki aktivitas antiinflamasi dengan nilai persentase penghambatan inflamasi secara berturut-turut sebesar 53,37\%, dan 49,95 \%. Adapun nilai $\mathrm{ED}_{50}$ yaitu sebesar 99,27 mg/KgBB.
\end{abstract}

Kata kunci: Antiinflamasi, bovine serum albumin, edema kaki tikus, nanopartikel, ekstrak teripang

\section{ABSTRACT}

Sea cucumber extract contains glucosamine which has potential to suppress inflammation and cure osteoarthritis. Nanoparticle technology used as a option to increase drug bioavailability. This study aimed to examine in vitro and in vivo anti-inflammatory activities of chitosan nanoparticles-dried extract of sea cucumber (Stichopus variegatus). Test for in vitro antiinflammatory activity was carried out using the protein denaturation method of Bovine Serum Albumin (BSA). The test results of the in vitro anti-inflammatory activity showed that the test preparations of chitosan nanoparticles-dried extract of sea cucumber had anti-inflammatory activities with an IC $C_{50}$ value of $267.76 \mathrm{ppm}$. Meanwhile, the test for in vivo anti-inflammatory activity was carried out using the method of carrageenan induction on the soles of the mouse paw with the parameter of edema assessment in the paw. This study used white mice of the SpragueDawley strain and devided into 4 groups., there were groups of mice which treated by chitosan nanoparticles-dried extract of sea cucumber (Stichopus variegatus) with a dose of $50 \mathrm{mg} / \mathrm{Kg} \mathrm{BW}$ 
and $100 \mathrm{mg} / \mathrm{KgBW}$, negative control (Aquadest) and positive control (Diclofenac sodium). The test results showed that the test preparations of chitosan nanoparticles-dried extract of sea cucumber with a dose of $50 \mathrm{mg} / \mathrm{Kg} \mathrm{BW}$ and $100 \mathrm{mg} / \mathrm{Kg} \mathrm{BW}$ had anti-inflammatory activity with percentage of inhibitory inflammation of $53.37 \%$ and $49.95 \%$. Meanwhile, ED5o of 99.27 $m g / K g B W$.

Keywords: Anti-inflammatory, bovine serum albumin, mouse paw edema, carrageenan, nanoparticles, sea cucumber extract

\section{PENDAHULUAN}

Inflamasi merupakan respon biologis kompleks dari jaringan pembuluh darah yang mengaktivasi sel darah putih, pelepasan sistem imun kimia seperti sitokin, serta pelepasan mediator inflamasi seperti prostaglandin karena adanya cedera, infeksi, pengaruh lingkungan, atau perubahan sel. Inflamasi juga merupakan upaya protektif tubuh untuk menghilangkan stimulus yang berbahaya dan memulai proses penyembuhan terhadap jaringan (Stankov, 2012).

Inflamasi dapat dikurangi dengan mengggunakan obat modern seperti golongan AINS (Antiinflamasi Non Steroid), namun obat golongan AINS ini memiliki efek samping pada tukak lambung. Efek samping tersebut dapat dikurangi, salah satunya dengan obat tradisional yang merupakan alternatif untuk dapat dimanfaatkan (Adnyasari et al., 2017).

Perkembangan obat herbal di Indonesia dapat ditingkatkan salah satunya dengan melakukan riset terhadap sumber daya alam hayati. Indonesia merupakan negara kepulauan, memiliki banyak potensi sumber daya alam yang dapat menghasilkan metabolit primer dan sekunder yang memberikan aktivitas biologis. Belum banyak penelitan terhadap sumber daya alam hayati laut. Salah satu biota laut yang terus diteliti sebagai bahan obat adalah teripang.

Teripang dilaporkan di berbagai negara di Asia sebagai obat tradisional untuk terapi luka dan beberapa penyakit. Penelitian yang dilakukan oleh (Pringgenies et al., 2018), melaporkan bahwa ekstrak teripang memiliki potensi dalam mengontrol kadar kolesterol dalam darah, sebagai antivirus, antimalaria dan antiarthritis. Peneliti (Janakiram et al., 2015), melaporkan bahwa ekstrak teripang terbukti dapat menekan peradangan (inflamasi) dan meningkatkan respons imun bawaan. Adapun penelitian yang dilakukan oleh Suryaningrum melaporkan bahwa senyawa glukosamin yang terdapat pada teripang terbukti dapat mengatasi peradangan sendi, rematik, dan osteoarthritis. Potensi 
pengembangan teripang sebagai obat herbal cukup tinggi, oleh karena itu diperlukan riset lanjutan dan juga teknologi farmasi untuk dapat memperoleh obat herbal yang efektif.

Penggunaan teknologi nanopartikel merupakan salah satu pilihan untuk meningkatkan bioavabilitas dan stabilitas obat. Nanopartikel merupakan drug system delivery partikel koloid submikron $(<1 \mu \mathrm{m})$ (Gelperina et al., 2005). Nanopartikel yang sering digunakan sebagai penghantar obat dan tidak berbahaya bagi tubuh manusia ialah nanopartikel kitosan (Putri et al., 2018).

Kitosan merupakan (poly- $\beta$-1,4-glukosamine) turunan dari kitin yang larut dalam asam asetat encer, asam laktat, asam malat, asam format dan asam suksinat. Kitosan telah digunakan secara luas dalam bidang biomedis karena sifat biokompatibilitasnya. Salah satu pemanfaatan kitosan dalam sistem biologis atau medis adalah pada sistem penghantaran dan pelepasan obat. Tripolifosfat (TPP) sebagai pengikat silang memiliki lebih banyak muatan negatif sehingga dapat berinteraksi lebih kuat dibandingkan polianion lain seperti sulfat dan sitrat. Selain itu, TPP juga nontoksik sehingga diharapkan tidak akan mengubah biokompatibilitas kitosan dan sesuai untuk aplikasi biomedis. Metode gelasi ionik dengan sonikasi digunakan untuk sintesis nanopartikel kitosan-TPP dan menghasilkan nanopartikel dengan diameter 563,1 $\pm 157,5 \mathrm{~nm}$ (Alauhdin and Widiarti, 2014).

Metode penghambatan denaturasi protein dapat dipakai sebagai skrining aktivitas antiinflamasi secara in vitro (Nargund and Redd, 1993). Metode ini mirip dengan reaksi hipersensitivitas tipe III yang yang ditandai dengan munculnya ekspresi antigen ketika albumin dipanaskan hingga terjadi denaturasi (Duganath et al., 2010). Potensi penghambatan inflamasi diperoleh dengan mengukur nilai densitas kekeruhan (turbiditas) menggunakan instrumen spektrofotometer visible pada panjang gelombang $660 \mathrm{~nm}$. Pengujian aktivitas antiinflamasi secara in vivo dapat dilakukan dengan pengukuran edema pada telapak kaki tikus yang diinduksi karagenan. Induksi inflamasi dengan karagenan merupakan cara yang sederhana dan rutin untuk evaluasi nyeri tanpa cedera atau kerusakan pada kaki yang meradang (Necas and Bartosikova, 2013). Tujuan penelitian ini adalah menentukan aktivitas antiinflamasi nanopartikel kitosan-ekstrak kering teripang secara in vitro dan in vivo. 


\section{METODE PENELITIAN}

\section{Alat dan Bahan}

Alat-alat yang digunakan dalam penelitian ini adalah seperangkat alat gelas dan kaca, botol minum, cawan, inkubator, kandang mencit, kertas saring, micropipet, neraca analitik, neraca hewan, Particle Size Analyzer (Malvern, UK), plestismometer manual, spektrofotometer UV-Visible dan Transmission Electron Microscope (TEM) (JEOL,1010, 80, KV).

Bahan yang digunakan dalam penelitian ini adalah asam asetat glasial (mallinckrods), aquadest, Bovine Serum Albumine, dimetil sulfoxide (merck), ekstrak kering teripang (Stichopus variegatus) yang diperoleh dari PT. Natura Nuswantara Nirmala, etanol 70\%, karagenan (RPInternationlimited), kitosan, natrium diklofenak, natrium klorida (merck), natrium tripolifospat, pakan tikus, propilenglikol dan tris base (Nacalai).

\section{Jalannya Penelitian}

Formulasi Nanopartikel Kitosan-Ekstrak Teripang

Formulasi sediaan nanopartikel kitosan-ekstrak teripang terlihat pada Tabel I.

Tabel I. Formulasi sediaan nanopartikel kitosan-ekstrak teripang

\begin{tabular}{cccc}
\hline Formula & $\begin{array}{c}\text { Ekstrak } \\
\text { teripang } \\
(\mathbf{m g} / \mathbf{m L})\end{array}$ & $\begin{array}{c}\text { Volume larutan } \\
\text { kitosan 1\% } \\
(\mathbf{m L})\end{array}$ & $\begin{array}{c}\text { Volume Natrium } \\
\text { Tripolipospat 0,1\% } \\
(\mathbf{m L})\end{array}$ \\
\hline 1 & 500 & 10 & 2 \\
2 & 500 & 10 & 3 \\
3 & 500 & 10 & 4 \\
4 & 500 & 10 & 5 \\
\hline
\end{tabular}

Pembuatan nanopartikel kitosan-ekstrak teripang

Sebanyak $500 \mathrm{mg}$ ekstrak kering teripang ditambahkan larutan campuran $20 \mathrm{~mL}$ DMSO 10\%, $20 \mathrm{~mL}$ propilenglikol, $20 \mathrm{~mL}$ etanol $70 \%$ dan $30 \mathrm{~mL}$ aquadest. Campuran tersebut ditambahkan larutan kitosan $1 \%(\mathrm{~b} / \mathrm{v})$ sebanyak $10 \mathrm{~mL}$ sehingga konsentrasi kitosan menjadi 0,1\%. Campuran tersebut diaduk menggunakan magnetic stirrer selama 10 menit. Selanjutnya ditetesi dengan NaTPP 0,1\% dan diaduk menggunakan magnetik stirrer $200 \mathrm{rpm}$ hingga terbentuk nanopartikel yang ditandai dengan kekeruhan yang homogen. Pengadukan dilanjutkan selama 15 menit agar didapat nanopartikel yang stabil. 
Evaluasi hasil pembuatan nanopartikel kitosan-ekstrak kering

Parameter evaluasi hasil pembuatan nanopartikel kitosan-ekstrak kering berdasarkan kestabilan yang diamati selama 5 hari meliputi warna, kekeruhan dan endapannya. Pemeriksaan distribusi, ukuran partikel dan potensial zeta dengan menggunakan particle size analyzer. Pemeriksaan morfologi partikel menggunakan alat Transmission Electron Microscope (TEM).

Pengujian aktivitas Anti-inflamasi in vitro

Setiap varian konsentrasi larutan uji dipipet $500 \mu \mathrm{L}$ kemudian ditambah larutan BSA $0,2 \%$ ke dalam labu ukur hingga volume $5 \mathrm{~mL}$. Semua larutan kemudian diinkubasi selama 30 menit pada suhu $\pm 25^{\circ} \mathrm{C}$ lalu dipanaskan selama 5 menit pada suhu $\pm 70{ }^{\circ} \mathrm{C}$ dengan water bath, kemudian didinginkan dengan cara direndam dalam wadah berisi air selama 10 menit pada suhu ruang. Setelah dingin larutan divortex dan diukur absorbannya dengan spektrofotometer UV-visible pada panjang gelombang $660 \mathrm{~nm}$, secara triplo. Data serapan yang diperoleh selanjutnya dihitung persentase inhibisinya.

Bovine Serum Albumin (BSA) mengalami denaturasi (perubahan struktur primer dan sekunder) pada saat dipanaskan yang ditandai dengan terjadi perubahan larutan uji yang semula berwarna bening menjadi keruh dan mengental (Farida et al., 2018).

Perhitungan Persentase Penghambatan Denaturasi Protein

Persentase penghambatan denaturasi protein diukur dengan menggunakan persamaan 1.

$$
\% \text { inhibisi }=\frac{\text { (absorbansi kontrol negatif-absorbansi larutan uji) }}{\text { (absorbansi kontrol negatif) }} \times 100 \%
$$

Nilai $\mathrm{IC}_{50}$ dihitung dengan membuat persamaan regresi linear antara konsentrasi (x) dengan $\%$ inhibisi (y). Pada uji inhibisi ini, jika dihasilkan $\%$ inhibisi $>20 \%$ dianggap memiliki aktivitas antiinflamasi (Farida et al., 2018).

Uji antiinflamasi in vivo

Sebelum dilakukan uji terhadap hewan coba, terlebih dahulu dilakukan pengurusan kode etik penelitian di Komisi Etik Pusat Studi Biofarmaka Tropika, Institut Pertanian Bogor (IPB), Bogor (Nomor: 003/2021/KEH TROP BEC). Hewan uji yang digunakan 
yaitu tikus putih jantan galur Sprague-Dawley berumur \pm 8 minggu dengan berat badan sekitar 200-250 gram yang diperoleh dari hasil breeding Unit Kandang Hewan Percobaan, Pusat Studi Biofarmaka LPPM IPB. Tikus diaklimatisasi selama 1 minggu agar dapat menyesuaikan diri dengan lingkungan sekitar. Selama aklimatisasi, hewan uji diberikan makan dan minum secukupnya. Pada tahap ini dilakukan pengamatan terhadap keadaan umum dan penimbangan berat badan setiap hari agar diperoleh hewan uji yang sehat. Sebelum pemberian larutan per oral hewan uji dipuasakan selama 8-10 jam kemudian volume kaki hewan uji diukur $\left(\mathrm{V}_{0}\right)$, kemudian larutan per oral diberikan (Indonesia, 2021). Tiga puluh menit setelah pemberian larutan per oral (sediaan uji) hewan uji diinduksi. Induksi inflamasi pada kaki tikus dilakukan dengan cara injeksi (subplantar) dengan $0,1 \mathrm{~mL}$ larutan karagenan $1 \%$.

Peningkatan volume diukur dengan alat pletismometer atau alat lain yang dirancang menurut hukum Archimedes. Kaki tikus ditandai sebagai batas pencelupan pada pletismometer. Edema pada telapak kaki diukur setiap 30 menit selama 6 jam setelah injeksi karagenan (Vt) (Indonesia, 2021).

Perhitungan volume edema dihitung dengan persamaan 2.

$$
\mathrm{Vu}=\mathrm{Vt}-\mathrm{Vn}
$$

Keterangan :

Vt : Volume kaki pada waktu ke-t (mL)

Vn : Volume kaki tikus normal ( sebelum injeksi karagenan) (mL)

Selanjutnya dihitung \%volume edema kaki (P) dengan persamaan 3.

$$
\% \text { Volume edema }(\mathrm{P})=\frac{V t-V n}{V n} \times 100 \%
$$

Perhitungan AUC (Area Under Curve) dihitung dengan metode trapezoid dengan persamaan 4.

$$
\mathrm{AUC}=\frac{P n+P n-1 / 2}{2} \times\left(\mathrm{t}_{\mathrm{n}}-\mathrm{t}_{\mathrm{n}-1 / 2}\right)
$$

Keterangan :

$\mathrm{P}_{\mathrm{n}}$

$\mathrm{P}_{\mathrm{n}-1 / 2}$

$t_{n}$

$t_{n-1 / 2}$
: Persentase volume edema jam ke-n

: Persentase volume edema $1 / 2$ jam sebelumnya

: waktu ke n (jam)

: waktu $1 / 2$ jam sebelumnya 
Selanjutnya perhitungan \% penghambatan edema menggunakan persamaan 5.

$\%$ Penghambatan edema $=\frac{\text { AUCkontrol }- \text { AUC test }}{\text { AUCkontrol }} \times 100 \%$

Keterangan :

$\mathrm{AUC}_{\text {kontrol }} \quad$ : rata-rata $\mathrm{AUC}$ volume edema kaki kontrol negatif

AUCt $_{\text {est }} \quad$ : rata-rata AUC volume yang diberi sediaan uji (Maharani \& muhtadi, 2017).

\section{Analisis Data}

Data hasil penelitian ini dianalisis secara statistik dimana hasil uji in vitro diuji menggunakan Kruskal-Wallis dan hasil uji in vivo diolah dengan uji ANOVA One Way menggunakan program SPSS versi 26 dengan hipotesis statistik sebagai berikut, nilai $p$ $<0,05$ sehingga $\mathrm{H}_{0}$ ditolak dan $\mathrm{H}_{1}$ diterima. $\mathrm{H}_{0}$ : tidak ada perbedaan bermakna antara nilai persentase hambatan inflamasi minimum 1 pasang kelompok uji per satuan waktu. $\mathrm{H}_{1}$ : ada perbedaan bermakna antara nilai persentase hambatan inflamasi minimum 1 pasang kelompok uji per satuan waktu.

\section{HASIL DAN PEMBAHASAN}

\section{Karakterisasi Organoleptis Serbuk Ekstrak Kering Teripang}

Sebelum dibuat nanopartikel, ekstrak teripang kering diuji organoleptis, uji ini dilakukan untuk menjaga mutu ekstrak. Hasil uji organoleptik ekstrak teripang kering dapat dilihat pada Tabel II dan Gambar 1.

Tabel II. Hasil Organoleptik Ekstrak Teripang kering

\begin{tabular}{cc}
\hline $\begin{array}{c}\text { Pengujian } \\
\text { Organoleptik }\end{array}$ & Hasil Pengujian \\
\hline Penampilan & Serbuk \\
Rasa & Sedikit manis \\
Warna & Putih agak \\
& kekuningan \\
Aroma & Khas teripang \\
\hline
\end{tabular}




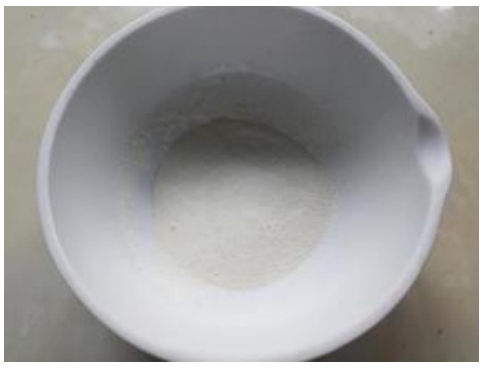

Gambar 1. Serbuk ekstrak teripang kering

Tabel II menampilkan hasil uji organoleptis serbuk ekstrak kering teripang. Rasa manis pada ekstrak ini dikarenakan adanya penambahan maltodekstrin. Secara umum, ekstrak merupakan bahan kompleks, amorf dan kental. Sifat afinitasnya tinggi untuk uap air, ekstrak cenderung higroskopis dan lengket serta memiliki sifat fisikomekanik yang rendah. Perubahan ekstrak menjadi ekstrak kering memiliki keuntungan yaitu biaya penyimpanannya lebih murah, konsentrasi lebih tinggi, zat aktif lebih stabil, mudah distandarisasi, mudah didistribusikan, dan mengurangi kontaminasi mikroba. Pada umumnya ekstrak kering digunakan pada pembuatan sediaan padat. Adapun penambahan maltodekstrin adalah sebagai drying aid yang memiliki kelarutan yang baik dan nilai Tg yang tinggi (Nining et al., 2017).

\section{Hasil Pembuatan Nanopartikel Kitosan-Ekstrak Teripang}

Kitosan digunakan sebagai polimer pada pembuatan nanopartikel dari ekstrak kering teripang (Stichopus variegatus). Keuntungan kitosan dalam sediaan nanopartikel adalah dalam segi keamanannya karena terbuat dari bahan alami, serta memiliki rentang bobot molekul luas sehingga cocok untuk katagori obat, selain itu kitosan juga memberikan peningkatan efek dengan memperpanjang kontak antara partikel dengan membran sel sehingga meningkatkan bioavailabilitas obat (Delie and Blanco-Príeto, 2005). Tripolifosfat (TPP) sebagai pengikat silang digunakan karena memiliki lebih banyak muatan negatif sehingga dapat berinteraksi lebih kuat dibandingkan polianion lain seperti sulfat dan sitrat. Selain itu, TPP juga nontoksik sehingga diharapkan tidak akan mengubah biokompatibilitas kitosan dan sesuai untuk aplikasi biomedis (Farida et al., 2018). 
Metode yang digunakan dalam pembuatan nanopartikel kitosan-ekstrak teripang adalah metode "buttom up" dengan teknik gelasi ionik. Teknik gelasi ionik yang melibatkan ikatan sambung silang antara kitosan dan sodium tripolifosfat dapat meningkatkan kestabilan dari nanopartikel yang terbentuk. Mekanisme pembentukan nanopartikel kitosan didasarkan pada interaksi elektrostatik antara amin dari kitosan dan muatan negatif dari polianion. Kitosan dapat dilarutkan dengan asam asetat. Polianion kemudian ditambahkan, sehingga terbentuk nanopartikel secara spontan dengan pengadukan magnetic stirrer pada suhu kamar (Abdassah, 2017).

Pada penelitian ini, dibuat 4 formula nanopartikel dimana perbedaan terletak pada variasi penambahan Natrium Tripolifosfat. Hasil dari pembuatan nanopartikel ini berupa nanosuspensi yang ditunjukkan pada gambar 2. Nanosuspensi kitosan-ekstrak teripang yang telah dibuat berwarna kuning dan sedikit keruh. Tantangan pada pembuatan nanosuspensi ini adalah pada saat melarutkan ekstrak kering dalam pelarut organik. Pada saat ekstrak kering dilarutkan dalam air, terdapat komponen yang tidak larut berwarna putih dan mengapung sehingga dilakukan optimasi pelarut yang bertujuan untuk memperoleh pelarut yang dapat melarutkan ekstrak kering dengan baik.

Ekstrak kering teripang dilarutkan dalam $20 \mathrm{~mL}$ DMSO 10\%, $20 \mathrm{~mL}$ propilenglikol dan $20 \mathrm{~mL}$ etanol $70 \%$, larutan tersebut disaring kemudian diadkan dengan aquadest hingga $90 \mathrm{~mL}$. Selanjutnya ditambahkan $1 \%$ kitosan sebanyak $10 \mathrm{~mL}$ sehingga hasil akhir konsentrasi kitosan adalah $0,1 \%$. Selanjutnya Natrium tripolifosfat $0,1 \%$ ditambahkan dengan volume sesuai formula. Pengadukan dilakukan pada suhu ruangan menggunakan magnetic stirer. Selanjutnya dilakukan uji stabilitas selama 5 hari pada semua formula nanopartikel yang sudah dibuat. 




Gambar 2. Nanosuspensi kitosan-ekstrak teripang

\section{Uji Stabilitas Fisik Nanopartikel Kitosan-Ekstrak Teripang}

Hasil uji stabilitas fisik nanopartikel ekstrak teripang dapat dilihat pada Tabel III.

Tabel III. Stabilitas fisik nanopartikel kitosan-ekstrak teripang

\begin{tabular}{cccccc}
\hline & Parameter & \multicolumn{4}{c}{ Formula } \\
\cline { 3 - 6 } & pengamatan & F1 & F2 & F3 & F4 \\
\cline { 3 - 6 } Hari ke-1 & Warna & Kuning & Kuning & Kuning & Kuning \\
& Kekeruhan & Stabil & Stabil & Stabil & Stabil \\
& Endapan & Tidak ada & Tidak ada & Tidak ada & Tidak ada \\
Hari ke-2 & Warna & Kuning & Kuning & Kuning & Kuning \\
& Kekeruhan & Tidak & Stabil & Stabil & Tidak Stabil \\
& & Stabil & & & \\
& Endapan & ada & Tidak ada & Tidak ada & ada \\
Hari ke-3 & Warna & Kuning & Kuning & Kuning & Kuning \\
& Kekeruhan & Tidak & Stabil & Stabil & Tidak Stabil \\
& & Stabil & & & \\
Hari ke-4 & Endapan & ada & Tidak ada & Tidak ada & Ada \\
& Warna & Kuning & Kuning & Kuning & Kuning \\
& Kekeruhan & Tidak & Tidak & Stabil & Tidak Stabil \\
& & Stabil & Stabil & & \\
& Endapan & ada & ada & Tidak ada & ada \\
Hari ke-5 & Warna & Kuning & Kuning & Kuning & Kuning \\
& Kekeruhan & Tidak & Stabil & Stabil & Tidak Stabil \\
& & Stabil & & & \\
& Endapan & ada & Tidak ada & Tidak ada & ada \\
\hline
\end{tabular}

Hasil pengamatan uji stabilitas dengan parameter warna, kekeruhan dan endapan selama 5 hari menunjukkan bahwa F3 merupakan nanopartikel yang paling stabil di 
bandingkan dengan F1, F2 dan F4, hal ini dapat terlihat dari hasil pengamatan pada hari ke -1 sampai hari ke-5 tidak ada perubahan pada parameter yang diamati, sehingga F3 ini dipilih untuk dilakukan uji selanjutnya.

\section{Hasil Karakterisasi Nanopartikel Kitosan-Ekstrak Teripang}

Hasil pemeriksaan distribusi dan ukuran partikel dari nanopartikel kitosan-ekstrak teripang menggunakan Particle size analyzer terlihat pada Tabel IV.

Tabel IV. Distribusi dan ukuran partikel

\begin{tabular}{lc}
\hline \multicolumn{1}{c}{ Parameter } & Hasil \\
\hline Ukuran rata-rata $(\mathrm{nm})$ & 336 \\
Indeks polidispersitas & 0,470 \\
\hline
\end{tabular}

Nanopartikel kitosan- ekstrak teripang memiliki ukuran partikel sebesar $336 \mathrm{~nm}$, artinya nanopartikel dari ekstrak teripang yang dibuat dengan metode gelasi ionic berhasil terbentuk dengan ukuran yang telah memenuhi syarat, dimana suatu partikel dikatakan berukuran nano bila berada pada rentang 1-1000 nm sehingga diharapkan mampu memberikan aktivitas yang baik (Farida et al., 2018). Distribusi ukuran partikel dinyatakan dalam indeks polidispersitas. Indeks polidispersitas merupakan jumlah yang dihitung dari dua parameter sederhana untuk data korelasi (cumulants). Hasil indeks polidispersitas nanopartikel yang telah dibuat yaitu 0,470, untuk partikel berukuran 100$300 \mathrm{~nm}$, nilai PDI di bawah 0,3 maka dapat dikatakan baik (Abdassah, 2017).

Hasil pemeriksaan potensial zeta dari nanopartikel kitosan-ekstrak kering teripang yaitu $+7.88 \mathrm{mV}$, nilai zeta potensial ini memungkinkan nanopartikel memiliki stabilitas yang rendah karena nanopartikel yang memiliki stabilitas tinggi memiliki nilai potensial zeta lebih kecil dari $-30 \mathrm{mV}$ dan lebih besar dari $+30 \mathrm{mV}$ (Abdassah, 2017). Beberapa faktor yang dapat mempengaruhi nilai potensial zeta diantaranya karakteristik muatan polimer, pH, dan karakteristik muatan ekstrak yang digunakan (Delie and Blanco-Príeto, 2005).

Bentuk dan permukaan nanopartikel diamati menggunakan Transmission Electron Microscopy (TEM). Hasil pemeriksaan morfologi nanopartikel kitosan-ekstrak teripang di Laboratorium TEM dan Histologi Lembaga Eijkman dapat dilihat pada Gambar 3. 
Nanopartikel kitosan-ektrak teripang dapat terbentuk dengan baik dimana globul memilikibentuk spheris yang cukup seragam.

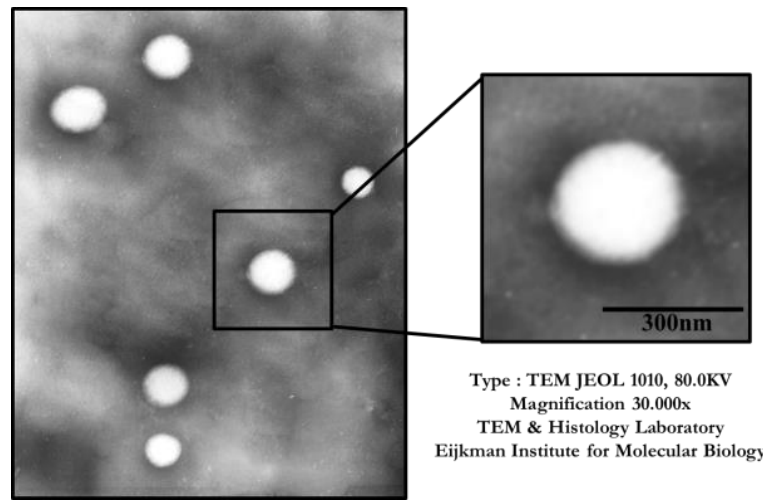

Gambar 3. Hasil pemeriksaan morfologi nanopartikel kitosan-ekstrak teripang menggunakan alat Transmission Electron Microscope (TEM)

\section{Aktivitas Antiinflamasi Secara In Vitro}

Hasil uji kontrol positif (natrium diklofenak) dan nanopartikel kitosan-ekstrak teripang dapat dilihat pada Tabel V dan VI.

Tabel V. Hasi uji aktivitas antiinflamasi kontrol positif (Natrium diklofenak)

\begin{tabular}{cccc}
\hline Konsentrasi (bpj) & Rata-rata serapan & $\begin{array}{c}\text { Rata-rata \% } \\
\text { inhibisi }\end{array}$ & $\begin{array}{c}\text { Rata-rata } \\
\text { IC50 (bpj) }\end{array}$ \\
\hline 3,13 & 0,6009 & 28,87 & \\
6,25 & 0,5337 & 36,83 & \\
12,5 & 0,4687 & 44,51 & $\mathbf{3 4 , 0 9}$ \\
25 & 0,4178 & 50,53 & \\
50 & 0,3288 & 61,08 & \\
100 & 0,211 & 75,02 & \\
kontrol negatif & 0,8448 & & \\
Rata-rata & & $\mathbf{4 9 , 4 7}$ & \\
\hline
\end{tabular}

Penentuan aktivitas antiinflamasi secara in vitro dapat menggunakan metode denaturasi protein Bovine Serum Albumin (BSA). BSA dipilih karena merupakan indikator denaturasi protein yang lebih peka dibandingkan dengan indikator albumin yang lainnya (Williams et al., 2008).

Larutan dapat memiliki aktivitas anti-inflamasi jika memiliki persen inhibisi lebih dari 20\% (Williams et al., 2008). Penentuan aktivitas antiinflamasi dilakukan terhadap kontrol negatif, kontrol positif, dan nanopartikel kitosan-ekstrak teripang (Stichopus variegatus). Pengujian ini dilakukan secara triplo. Dari data tersebut diperoleh larutan 
kontrol positif pada konsentrasi 12,5 bpj sudah dapat menghambat denaturasi potein dengan hasil rata-rata persen inhbisi $49,47 \%$, sedangkan penghambatan denaturasi protein pada larutan nanopartikel kitosan-ekstrak teripang ditunjukkan pada konsentrasi 25 bpj dengan hasil rata-rata persen inhibisi 42,49\%. Teknologi nanopartikel merupakan sistem penghantaran obat paling baik karena memiliki keuntungan yaitu dapat memberikan penghantaran obat terkendali, melindungi zat aktif dari degradasi enzimatik dan lingkungan serta memperpanjang waktu kontak (Delie and Blanco-Príeto, 2005).

Tabel VI. Hasil uji aktivitas antiinflamasi nanopartikel kitosan-ekstrak kering teripang (Stichopus variegatus)

\begin{tabular}{cccc}
\hline $\begin{array}{c}\text { Konsentrasi } \\
\text { (bpj) }\end{array}$ & $\begin{array}{c}\text { Rata-rata } \\
\text { serapan }\end{array}$ & $\begin{array}{c}\text { Rata-rata \% } \\
\text { inhibisi }\end{array}$ & $\begin{array}{c}\text { Rata-rata IC50 } \\
\text { (bpj) }\end{array}$ \\
\hline 25 & 0,6617 & 22,12 & \\
50 & 0,5927 & 30,24 & \\
100 & 0,563 & 36,17 & \\
200 & 0,4444 & 47,7 & $\mathbf{2 6 7 , 7 6}$ \\
400 & 0,2126 & 74,99 & \\
800 & 0,1174 & 86,19 & \\
kontrol negatif & 0,8497 & & \\
\hline Rata-rata & & $\mathbf{4 9 , 5 6}$ &
\end{tabular}

Persen inhibisi dari tiap-tiap seri larutan kontrol positif dan larutan nanopartikel kitosan-ekstrak teripang (Stichopus variegatus) dihitung dari nilai regresi liniernya. Hasil perhitungan dari tiap-tiap regresi linier larutan tersebut menunjukkan nilai positif, sehingga daya penghambatan denaturasi proteinnya sebanding dengan konsentrasi yang diujikan. Semakin besar konsentrasi yang diuji maka daya penghambatan denaturasi proteinnya semakin besar.

Hasil dari uji aktivitas antiinflamasi secara in vitro diperoleh nilai $\mathrm{IC}_{50}$. $\mathrm{IC}_{50}$ menunjukkan efektivitas nanopartikel dalam menghambat denaturasi protein. Nilai IC $_{50}$ merupakan konsentrasi saat persentase penghambatan denaturasi protein mencapai nilai $50 \%$. Hasil perhitungan $\mathrm{IC}_{50}$ rata-rata pada kontrol positif (natrium diklofenak) yaitu sebesar 34,09 bpj dan pada nanopartikel kitosan- ekstrak kering teripang adalah sebesar 267,76 bpj. Hasil analisis dengan uji Kruskal-Wallis menunjukkan nilai P-Value = 0,385 $>\alpha=0,05$ sehingga $\mathrm{H}_{0}$ diterima dan $\mathrm{H} 1$ ditolak yang berarti bahwa semua pemberian 
perlakuan memberikan rata-rata persentase inhibisi in vitro yang sama. Dengan demikian, semua perlakuan tidak memberikan perbedaan persentase inhibisi yang signifikan.

Aktivitas antiinflamasi secara in vivo

Setelah diperoleh volume edema kaki tikus yang diinduksi karagenan, nilai persentase edema kaki dapat diperoleh. Selanjutnya dilakukan perhitungan nilai AUC yang menggambarkan besarnya edema yang ditunjukkan pada gambar 4 .

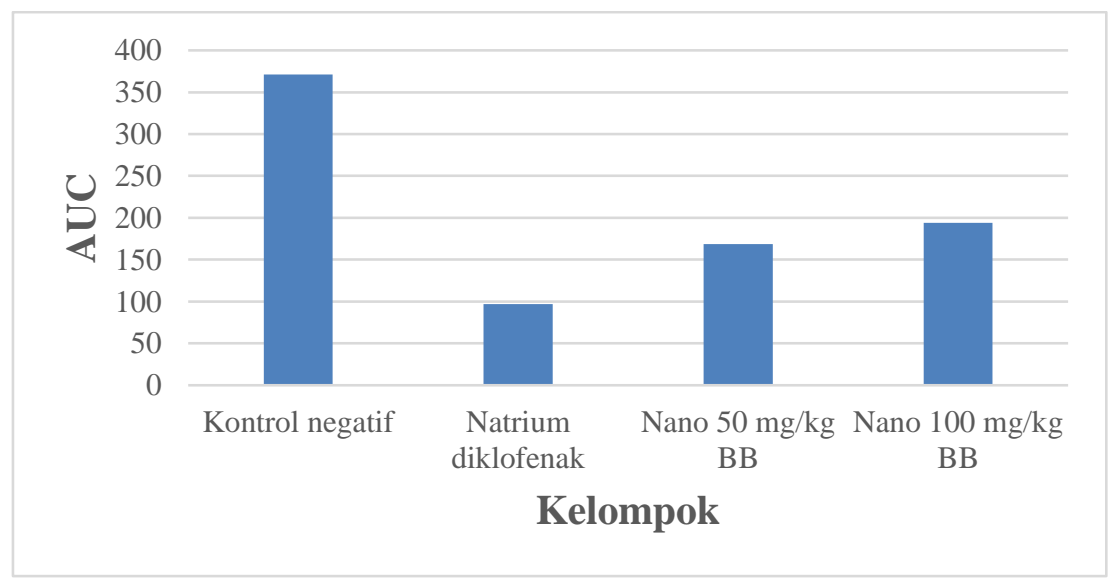

Gambar 4. Nilai AUC Rata-rata Penghambatan Edema Tiap Kelompok

Pada Gambar 4 menunjukkan bahwa setiap kelompok uji memiliki nilai AUC yang lebih rendah dari kontrol negatif. Persentase penghambatan edema pada variasi waktu terlihat pada Gambar 5.

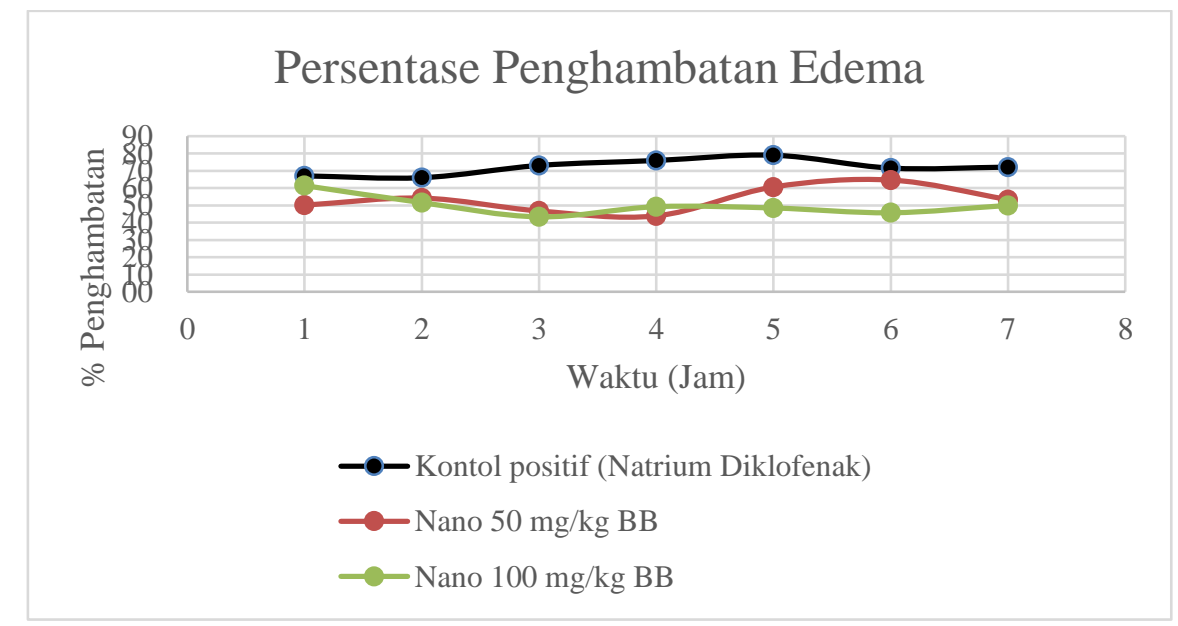

Gambar 5. Persentase Penghambatan Edema pada variasi waktu 
Gambar 5. merupakan kurva persentase penghambatan edema pada waktu pengamatan ke 1, 2, 3, 4, 5 dan 6 (jam). Dalam pembacaan kurva persentase hambatan inflamasi, yang perlu diperhatikan adalah menit ke-120 dan 180 (Pengamatan ke- 2 dan pengamatan ke-3) karena pada menit-menit tersebut terjadi pelepasan mediator inflamasi yang dipicu oleh penginduksian karagenan. Waktu terbentuknya radang akibat dari induksi karagenan terdiri dari dua fase. Fase pertama (early phase), yaitu 1-2 jam setelah injeksi karagenan dimana terjadi lepasnya serotonin dan histamin ke tempat radang serta terjadi peningkatan sintesis prostaglandin pada jaringan yang rusak. Pada fase kedua (late phase) terjadi pelepasan prostaglandin 3 jam setelah induksi karagenan, kemudian edema berkembang cepat dan bertahan pada volume maksimal sekitar 5 jam setelah induksi (Adnyasari et al., 2017). Berdasarkan penjabaran tersebut, pada fase pertama yang ditunjukkan pada Gambar 5, sediaan uji mampu menghambat edema pada kaki tikus yang diinduksi karagenan namun nanopartikel $100 \mathrm{mg} / \mathrm{KgBB}$ mengalami penurunan \% penghambatan kurang lebih 10\%. Pada fase kedua, semua sediaan uji mengalami penurunan $\%$ penghambatan edema dibandingkan kontrol positifnya yang stabil mengalami peningkatan $\%$ penghambatan edema. Persen penghambatan edema pada sediaan uji terlihat pada Tabel VI.

Tabel VI. Persen penghambatan edema pada sediaan uji

\begin{tabular}{cccc}
\hline Kelompok & $\begin{array}{c}\text { Dosis } \\
(\mathbf{m g} / \mathbf{K g B B})\end{array}$ & $\begin{array}{c}\text { Persen } \\
\text { Penghambatan }(\%)\end{array}$ & $\begin{array}{c}\text { ED50 } \\
(\mathbf{m g} / \mathbf{K g B B})\end{array}$ \\
\hline Kontrol negatif & 0 & 0 & \\
Natrium & 50 & 72,10 & \\
Diklofenak & & & 99,27 \\
Nanopartikel 1 & 50 & 53,37 & \\
Nanopartikel 2 & 100 & 49,95 & \\
\end{tabular}

Dalam pengujian aktivitas antiinflamasi, indikator penting yang dapat diamati adalah persentase hambatan edema atau persentase inflamasi. Besarnya persentase hambatan inflamasi menunjukkan seberapa efektif tiap sampel uji atau obat pembanding yang digunakan dalam menekan edema kaki tikus yang dihasilkan oleh induksi karagenan. Tabel VI menujukkan \% penghambatan edema setiap sediaan uji. Pada sediaan uji nanopartikel terlihat bahwa semakin tinggi dosis yang diberikan, persentase hambatan antiinflamasinya semakin menurun. Hal ini kemungkinan disebabkan terdapat 
beberapa jenis obat dalam dosis tinggi justru menyebabkan pelepasan histamin secara langsung dari sel mast sehingga mengakibatkan pembuluh darah menjadi permeabel terhadap cairan plasma dan menimbulkan peradangan (Adnyasari et al., 2017). Adapun diperoleh nilai ED50 yang dihitung dengan regresi linier, yaitu sebesar 99,27 mg/KgBB.

\section{KESIMPULAN}

Berdasarkan hasil penelitian, dapat disimpulkan bahwa nanopartikel kitosanekstrak teripang menunjukkan aktivitas antiinflamasi baik secara in vitro maupun in vivo yang ditunjukkan dengan nilai $\mathrm{IC}_{50}$ sebesar 267,76 bpj dan nilai $\%$ penghambatan 53,37\% $49,95 \%$ pada dosis $50 \mathrm{mg} / \mathrm{KgBB}$ dan $100 \mathrm{mg} / \mathrm{KgBB}$ tikus secara berturut-turut.

\section{DAFTAR PUSTAKA}

Abdassah, M. (2017). Nanopartikel dengan Gelasi Ionik. Farmaka, 15(1).

Adnyasari, I. A. P. S., Puspawati, N. M., \& Sukadana, I. M. (2017). Potensi antiimplamasi secara in vivo ekstrak etanol batang antawali (Tinospora sinensis) pada tikus wistar yang diinduksi karagenan. Cakra Kimia (Indonesian E-Journal of Applied Chemistry), 5(5), 113-119.

Alauhdin, M., \& Widiarti, N. (2014). Sintesis dan modifikasi lapis tipis kitosantripolifosfat. Indonesian Journal of Mathematics and Natural Sciences, 37(1), 4652.

Delie, F., \& Blanco-Príeto, M. J. (2005). Polymeric particulates to improve oral bioavailability of peptide drugs. Molecules, 10(1), 65-80.

Duganath, N., Sadasivam, R. K., Raghunathan, K., \& Jayaveera, K. N. (2010). Evaluation of anti- denaturation property and anti-oxidant activity of traditionally used medicinal plants. Internation Journal of Pharma and Bio Sciences, 1(2), 1-7.

Farida, Y., Rahmat, D., \& Amanda, A. W. (2018). Uji antiinflamasi nanopartikel ekstrak etanol temulawak (Curcuma Xanthorrhiza R) dengan metode penghambatan 
denaturasi protein. Jurnal Ilmu Kefarmasian Indonesia, 16(2), 225-230.

Gelperina, S., Kisich, K., Iseman, M. D., \& Heifets, L. (2005). The potential advantages of nanoparticle drug delivery systems in chemotherapy of tuberculosis. American Journal of Respiratory and Critical Care Medicine, 172(12), 1487-1490.

Indonesia, D. K. R. (2021). Rancangan PERKABPOM pedoman uji Farmakodinamik pra klinik obat tradisional. Direktorat Jendral Pengawasan Obat dan Makanan.

Janakiram, N. B., Mohammed, A., \& Rao, C. V. (2015). Sea cucumbers metabolites as potent anti-cancer agents. Marine Drugs, 13(5), 2909-2923.

Nargund, L. V, \& G R Redd, V. H. (1993). Inhibition of albumin denaturation and antiinflammatory activity of acetamido [(phenyl-4'-yl)-oxymethyl)]2-(p-substituted phenylamino)-1,2,4-triazoles and -1,3,4-thiadiazoles. Indian Journal of Experimental Biology., 31(4), 395-396.

Necas, J., \& Bartosikova, L. (2013). Carrageenan : a review. 2013(4), 187-205.

Nining, N., Seowandhi, S. N., \& Wikarsa, S. (2017). Pengeringan ekstrak bunga rosella (Hibiscus sabdariffa L) melalui mikroenkapsulasi metode semprot kering dengan maltodekstrin. Farmasains, 4(2), 65-71.

Pringgenies, D., Rudiyanti, S., \& Yudiati, E. (2018). Exploration of sea cucumbers stichopus hermanii from karimunjawa islands as production of marine biological resources. IOP Conf. Series Earth and Environmental Science., 116(1), 1-8.

Putri, A. I., Sundaryono, A., \& Chandra, I. N. (2018). Karakterisasi nanopartikel kitosan eksrak daun ubi jalar (Ipomoea batatas L.) menggunakan metode gelasi ionik. Alotrop, 2(2), 203-207.

Stankov, S. (2012). Definition of inflammation, causes of inflammation and possible antiinflammatory strategies. The Open Inflammation Journal, 5(1), 1-9. 
Williams, L. A. D., O’Connar, A., Latore, L., Dennis, O., Ringer, S., Whittaker, J. A., Conrad, J., Vogler, B., Rosner, H., \& Kraus, W. (2008). The in vitro antidenaturation effect induced by natural product and non steroidal compounds in heat treated (immunogenic) bovine serum albumin is proposed as a screening assay for the detection of anti-inflammatory compunds, without the use of animals, in. West Indian Medical Journal, 57(4), 327-330. 